\title{
Consequences of solar radiation on bacterial secondary production and growth rates in subtropical coastal water (Atlantic Coral Reef off Belize, Central America)
}

\author{
Ryszard J. Chróst ${ }^{1, *}$, Maria A. Faust ${ }^{2}$

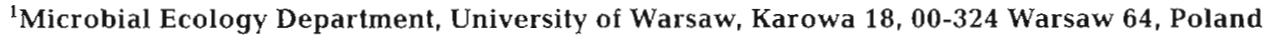 \\ ${ }^{2}$ Department of Botany, National Museum of Natural History, Smithsonian Institution, Suitland, Maryland 20746, USA
}

\begin{abstract}
This study reports the effects of natural solar radiation on production and growth rates of bacterial assemblages in coastal surface water of the Atlantic Barrier Coral Reef off Belize, Central America. Bacterial production rates measured in the late afternoon were significantly lower than rates measured in the morning. There were also significant differences in the specific growth rates of bacterial assemblages between water samples: bacteria grew faster, i.e. displayed shorter doubling times, in the early morning. Bioassay experiments showed a significant increase in rates of bacterial secondary production in water samples exposed in situ to ambient solar radiation at the water surface. There was also a pronounced increase in the growth rates and cell volumes of bacteria grown in sunlight-irradiated water samples. We suggest that enhanced metabolism of bacteria grown in water samples that were previously exposed to solar radiation was due mainly to photodegradation of dissolved organic matter and subsequent enrichment of water with easily utilizable substrates. The results of these studies indicate that solar radiation can directly alter bacterial production and growth over diel cycles in subtropical waters. These physico-chemical and biological interactions between solar radiation and heterotrophic bacteria in subtropical coastal water may have important biogeochemical implications at both the ecosystem and global levels.
\end{abstract}

KEY WORDS: Bacterial production - Bacterial growth rates S Solar radiation - Subtropical coastal waters

\section{INTRODUCTION}

Solar radiation is the primary source of energy in most aquatic and terrestrial ecosystems. It plays a pivotal role in regulating the rate of inorganic nutrient uptake and in the synthesis of organic matter in all phototrophic organisms, as well as controlling their distribution and abundance on our planet (Larchar 1995). It also controls the allocation, behavior and metabolic activity of a variety of non-photosynthetic macroorganisms (Luecke \& O'Brien 1981, Lampert 1989, Siebeck \& Böhm 1994) and microorganisms in natural environments (Sieracki \& Sieburth 1986, Lindell \& Edling 1996). Moreover, the potential for high levels of solar radiation in surface waters to suppress or

\footnotetext{
•E-mail: chrost@plearn.edu.pl
}

damage aquatic microorganisms has been recognized for some time (Holm-Hansen et al. 1993b). Environmental exposure to solar radiation has been an essential and integral part of the evolution of many species and communities of terrestrial and aquatic organisms. In aquatic ecosystems, solar radiation sets up a pronounced vertical habitat gradient along which the activity and abundance of aquatic microorganisms (algae, cyanobacteria, bacteria, protozoans) vary according to fluctuations in light spectrum and intensity, nutrients and food supply, grazers, viruses, and other environmental factors (Bailey et al. 1983, Riemann \& Søndergaard 1984, Suttle et al. 1993, Jeffrey et al. 1996, Sommaruga et al. 1996, Bergeron \& Vincent 1997, Weinbauer et al. 1997, Pakulski et al. 1998).

Solar radiation is highly variable over a range of scales, from minutes and hours to days and weeks. At 
the surface of aquatic ecosystems, these fluctuations are due to changes in a variety of factors, including solar zenith angle, atmospheric aerosols, amount of ozone in the stratosphere, density of cloud cover, and elevation above the sea level (Madronich 1992, Kirk 1994). In the water column, the penetration of solar radiation, particularly UV-B (280 to $320 \mathrm{~nm}$ ) and UV-A (320 to $400 \mathrm{~nm}$ ) wavelengths, depends strongly on absorption and scattering of dissolved and particulate organic matter and water itself (Smith \& Baker 1981, Scully \& Lean 1994, Williamson et al. 1996). Several studies have shown that UV wavelengths of the sunlight spectrum can penetrate into much deeper layers of the photic zone of marine and freshwater ecosystems than previously thought (Jerlov 1950, Smith \& Baker 1979, Fleischman 1989, Karentz \& Lutze 1990).

In the last decade, interest in the role of solar radiation spectra in aquatic ecosystems has grown due to the steady decline in stratospheric ozone content thal results in significant increases of biologically harmful UV-B radiation, of up to 10 to $20 \%$ per decade, reaching the earth's surface (Tevini 1993, Madronich 1994). This is now known to be due to the anthropogenic effects of chemical pollutants accelerating the natural photolysis of stratospheric ozone. Because little radiation with wavelengths below $300 \mathrm{~nm}$ penetrates the atmosphere, most of the UV radiation of biological significance is within the UV-B ( 300 to $320 \mathrm{~nm}$ ) waveband (Kirk 1994).

There is a large base of literature indicating that UV radiation, particularly UV-B, imposes stress on a variety of aquatic organisms (e.g. Herndl et al. 1993, HolmHansen et al. 1993a,b, Cullen \& Neale 1994, Williamson 1995, Aas et al. 1996, Lesser 1996. Wilhelm et al. 1998). Most of these studies have focused on algal photosynthesis and primary production in marine environments. These studies demonstrate severe inhibition of these processes by UV-B radiation (Helbling et al. 1992, Holm-Hansen et al. 1993a, Nielsen \& Ekelund 1995, Häder 1996, Sundbäck et al. 1996). However, relatively little work has been devoted to the effects of natural solar radiation on natural bacterial communities and their in situ metabolic activities, growth rates, and secondary production in aquatic ecosystems. Existing studies suggest that these microbial heterotrophic communities and their metabolic rates can be significantly altered, negatively or positively, by short-wavelength solar radiation (Bailey et al. 1983, Sieracki \& Sieburth 1986, Herndl et al. 1993, Lindell et al. 1995, 1996, Müller-Niklas et al. 1995, Wetzel et al. 1995, Aas et al. 1996, Jeffrey et al. 1996, Lindell \& Edling 1996, Pakulski et al. 1998).

It is now commonly accepted that heterotrophic bacteria are important to the functioning of all aquatic ecosystems (Williams 1981, Azam et al. 1983). Bacteria are the predominant decomposers and consurners of dissolved organic substances in waters and sediments (Azam \& Ammerman 1984, Münster \& Chróst 1990, Chróst 1993, 1994) and mediate the flux of organic and inorganic matter in aquatic ecosystems (Cho \& Azam 1990, Chróst 1991, Alongi 1994). The production of bacterial biomass represents an important link between dissolved organic carbon (DOC) and higher trophic levels in aquatic ecosystems. By virtue of their abundance, low substrate affinities and potentially rapid growth rates, bacteria are capable of rapidly converting energetically low labile DOC into their biomass, i.e. high-quality bacterial particulate organic matter that is efficiently utilized by bacterivorous protozoans and other aquatic organisms (Ducklow \& Carlson 1992, Sanders et al. 1992, Chróst \& Rai 1994).

Because the transformation of organic substances from the DOC pool into bacterial biomass is the crucial slep in organic matier processing and directiy affects its flux to higher trophic levels in aquatic ecosystems, we studied the impact of natural high solar radiation on bacterial secondary production (BP) and growth rates of bacterial assemblages in subtropical coastal surface waters. The possible effects of solar irradiance on bacterial carbon cycling in aquatic ecosystems are discussed.

\section{MATERIALS AND METHODS}

Sampling site. We conducted our studies at the Atlantic Barrier Coral Reef off Belize, Central America $\left(16^{\circ} 48^{\prime} \mathrm{N}, 88^{\circ} 05^{\prime} \mathrm{W}\right)$ in May 1996 and May 1997. Surface (0 to $0.5 \mathrm{~m}$ layer) water samples (2 l) were collected from the coastal lagoon waters around Carrie Bow Cay, and from The Lair, an embayment of Twin Cays (Fig. 1). Carrie Bow Cay and Twin Cays are small, undisturbed islands located just inside the Tobacco Reef section of the barrier reef of Belize. This feature is the longest barrier reef of the northern hemisphere. The sampling sites represented 2 distinct environments: the 10 to $12 \mathrm{~m}$ deep lagoon at Carrie Bow Cay contained clear and oligotrophic oceanic water, while The Lair ( 2 to $3 \mathrm{~m}$ deep) was an eutrophic site with inputs of organic matter from the red mangrove Rhizophora mangle (Ruetzler \& Feller 1988, Faust \& Gulledge 1996).

Bacterial production. BP $\left({ }^{3} \mathrm{H}\right.$-thymidine incorporation method, Chróst \& Rai 1994) was measured twice a day, between 06:00 and 07:00 $\mathrm{h}$ and $1 \mathrm{~h}$ before sunset ( 17:30 h) from May 17 to May 30, 1996. Incorporation of [ ${ }^{3} \mathrm{H}$-methyl]thymidine $(\mathrm{TdR}$; DuPont NEN, specific activity $97.5 \mathrm{Ci} \mathrm{mmol}^{-1} ; 15.4 \mathrm{nM}$ final concentration in assay) into the ice-cold TCA precipitate was measured in triplicate $10 \mathrm{ml}$ samples corrected for formalin-fixed 


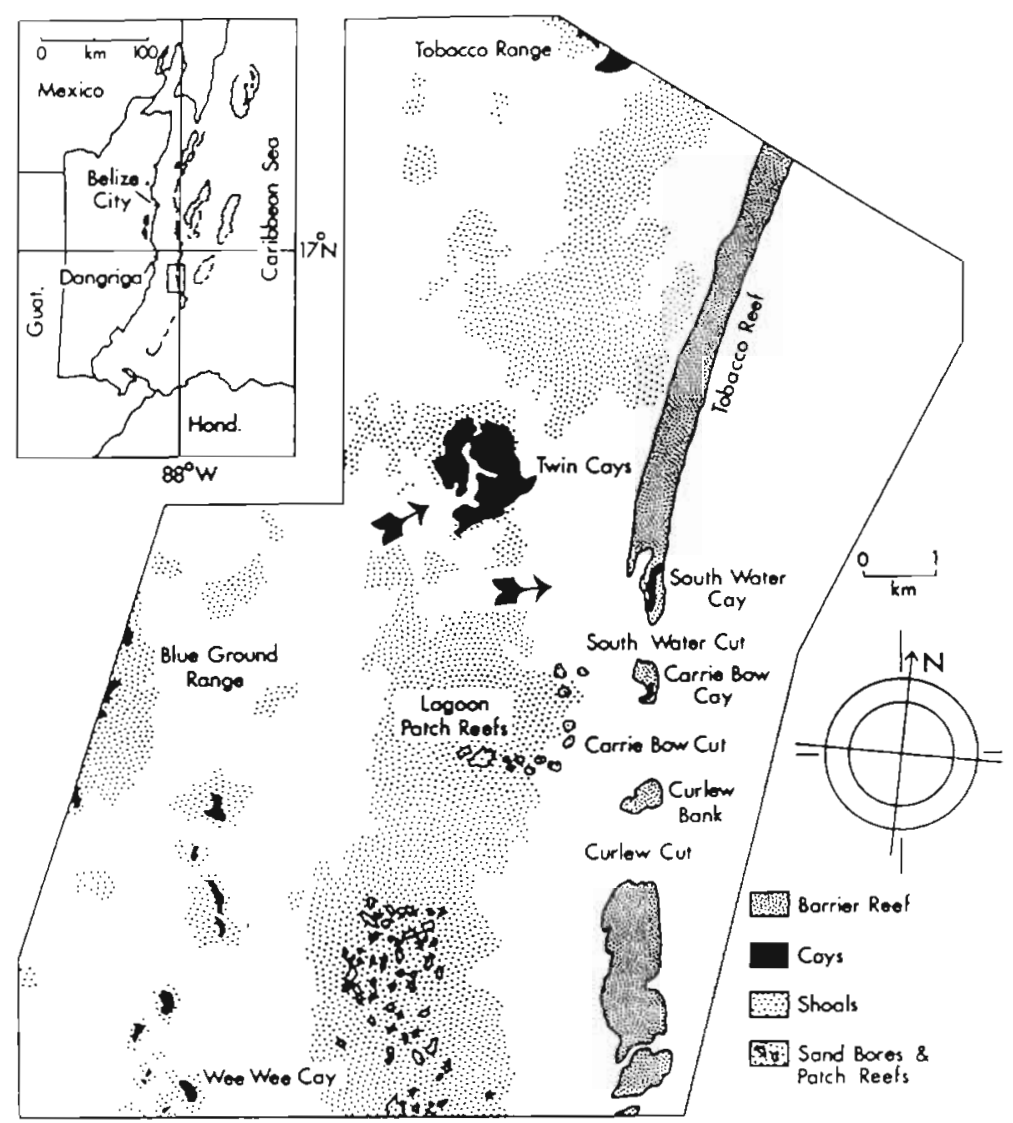

Fig. 1. Location of study site: Carrie Bow Cay and Twin Cays. Black arrows show sampling sites

Incorporation of $\left[{ }^{3} \mathrm{H}\right.$-methyl]thymidine and $\left[{ }^{3} \mathrm{H}\right.$ leucine in water samples continuously exposed to solar radiation. We determined rates of $\mathrm{TdR}$ and $\left[{ }^{3} \mathrm{H}\right]$ leucine incorporation in the lagoon and Lair water samples that were continuously exposed to natural high solar radiation in quartz and polystyrene vessels. Water samples (0 to $0.25 \mathrm{~m}$ surface layer) were taken 2 h after sunrise. Samples were gravity filtered $(0.8 \mu \mathrm{m}$ pore size, diameter $47 \mathrm{~mm}$, polycarbonate membrane filters, Nuclepore, prerinsed with deionized water) to eliminate bacterivores. Duplicate subsamples were distributed into a series of sterile polystyrene $100 \mathrm{ml}$ tissue culture flasks (Becton Dickinson Labware, NJ) and $10 \mathrm{ml}$ quartz cuvettes. Flasks and cuvettes were exposed horizontally in situ for $6 \mathrm{~h}$ to natural solar radiation at the water surface $(0.25 \mathrm{~m})$. Duplicate control vessels were covered with aluminum foil and incubated in situ. TdR (as described above) and $\left[{ }^{3} \mathrm{H}\right]$ leucine incorporation (15 $\mathrm{nM}$ final concentration, specific activity $50 \mathrm{Ci} \mathrm{mmol}^{-1}$, DuPont NEN; Simon \& Azam 1989) was determined in samples after 6 h of sunlight exposure.

Growth of bacteria in water samples previously exposed to solar radiation. To avoid the use of highly expensive

blanks ( $4 \%$ final concentration) in $20 \mathrm{ml}$ glass scintillation vials $(0.1 \mathrm{~N} \mathrm{HCl-cleaned} \mathrm{and} \mathrm{pre-rinsed} \mathrm{with}$ water from the respective sampling sites) at in situ temperature $\left(30\right.$ to $\left.32^{\circ} \mathrm{C}\right)$. Samples were incubated in the dark for $0.5 \mathrm{~h}$. Radioactivity of TCA precipitate, collected on $0.2 \mathrm{\mu m}$ pore size polycarbonate filters (Poretics), was determined using the external standard channels ratio method with a 1215 RackBeta II (LKB Wallac) liquid scintillation counter.

Experimentally derived conversion factors were calculated from simultaneous determinations in the increase in bacterial cell numbers and integrated thymidine incorporation rates at 6 to $8 \mathrm{~h}$ intervals in 11 $0.8 \mu \mathrm{m}$ (polycarbonate membrane filters, Poretics) filtered samples over a $32 \mathrm{~h}$ incubation period. These were applied to convert pmoles of incorporated thymidine to cell BP (Chróst \& Rai 1994). Mean conversion factors for BP in lagoon and Lair samples were $1.15 \pm$ $0.06 \times 10^{6}$ cells pmol $^{-1} \mathrm{TdR}(\mathrm{n}=5)$ and $1.38 \pm 0.12 \times 10^{6}$ cells pmol ${ }^{-1} \mathrm{TdR}(\mathrm{n}=5)$, respectively. Cell BP was converted to biomass production by means of cell-to-biomass conversion factor $19.8 \mathrm{fg} \mathrm{C}^{-1}$ cell $^{-1}$ (Lee \& Fuhrman 1987). quartz vessels for solar exposure of water samples we used polystyrene tissue culture flasks. Surface $(0.25 \mathrm{~m})$ water samples, taken $0.5 \mathrm{~h}$ after sunrise, were filtersterilized using polycarbonate membrane filters $(0.2 \mu \mathrm{m}$ pore size, diameter $47 \mathrm{~mm}$, pre-rinsed with deionized water, Poretics). Subsamples $(85 \mathrm{ml})$ were distributed into a series of sterile $100 \mathrm{ml}$ polystyrene $10.1 \mathrm{~N} \mathrm{HCl}$ cleaned and pre-rinsed with water from the respective sampling sites) tissue culture flasks (Becton Dickinson Labware). Triplicate flasks were horizontally exposed for 3 and $6 \mathrm{~h}$ (from 10:00 to 16:00 h) to natural solar radiation at the water surface $(0.25 \mathrm{~m})$. Triplicate controls were covered with aluminum foil. During exposure of water samples, total solar radiation (300 to $700 \mathrm{~nm}$ ) and UV (300 to $400 \mathrm{~nm}$ ) were monitored at $0.5 \mathrm{~h}$ intervals (2 $\mathrm{nm}$ wavelength scan range) with LI-1800 UV underwater spectroradiometer (LI-COR). The light sensor (at $0.25 \mathrm{~m}$ depth) was covered with a polystyrene flask wall to measure actual radiation passing to exposed samples.

After exposure, water samples were re-inoculated with $1.5 \mathrm{ml}$ of gravity-filtered $(0.8 \mu \mathrm{m}$ pore-size, polycarbonate membrane filters, Nuclepore) water con- 
taining natural bacteria from the respective sampling sites. Microscopic examination of $0.8 \mu \mathrm{m}$ filtered fixed samples revealed that prefiltration of water inoculum eliminated about 92 to $96 \%$ of bacterial grazers naturally present in the lagoon and Lair water. BP and abundance (DAPI counts, see below) in water samples during $24 \mathrm{~h}$ growth of bacteria in the dark were determined at selected intervals. Specific growth rates $(\mu)$ of bacteria were calculated from the slope of linear regression of natural logarithms of TdR incorporation and bacterial numbers versus incubation time, determined simultaneously during growth experiments (Chróst et al. 1988). Assuming exponential growth of bacteria during experiments, the doubling times were calculated from $\ln 2 / \mu$.

Bacterial abundance and cell volume. Epifluorescence microscopy was used to determine bacterial cell numbers and biovolume. Glutaraldehyde preserved ( $2 \%$ final concentration), and 4,6-diamidino-2-phenylindole (DAPI) stained samples were counted for bacterial abundance (Porter \& Feig 1980). Epifluorescence photomicrography was used to examine cell size (Lee \& Fuhrman 1987). Photographs (Kodak Ektachrome 400 ASA) were taken from 5 randomly selected fields of each microscope slide within $0.5 \mathrm{~h}$ of its preparation. Photographic images were projected onto a screen (final magnification -20000 ) and 250 to 300 cells per photographic slide were measured to determine bacterial cell size and to calculate cell volume.

Turnover time of bacterial biomass. The turnover time of bacterial biomass was determined as bacterial biomass $\left(\mu \mathrm{g} \mathrm{Cl}^{-1}\right)$ divided by $\mathrm{BP}\left(\mu \mathrm{g} \mathrm{C} \mathrm{l}^{-1} \mathrm{~h}^{-1}\right)$. Biomass of bacteria in the lagoon and the Lair water samples was calculated by multiplying bacterial cell numbers (DAPI counts) by the cell-to-biomass conversion factor of 18.7 and $23.3 \mathrm{fg} \mathrm{C}$ cell $^{-1}$, respectively (Simon \& Azam 1989).

Statistical analysis. Experimental data were statistically analyzed (multiple regression analysis and ANOVA) according to Helsel \& Hirsch (1992) using computer software (Statistix, Analytical Software, USA).

\section{RESULTS}

\section{Bacterial production}

Bacterial secondary production (BP) varied markedly between the sampling sites during the study period (Fig. 2). In the oligotrophic lagoon (Fig. 2A), daily mean BP $\left(0.41 \pm 0.08 \mu \mathrm{g} \mathrm{C} \mathrm{l}^{-1} \mathrm{~h}^{-1}\right)$ was $\sim 4.2$ times lower

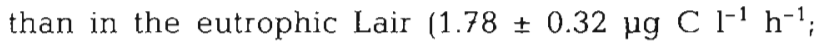
Fig. $2 \mathrm{~B}$ ). At both sites, the rates of $\mathrm{BP}$ measured in the late afternoon were significantly lower (ANOVA, $\mathrm{p}=$
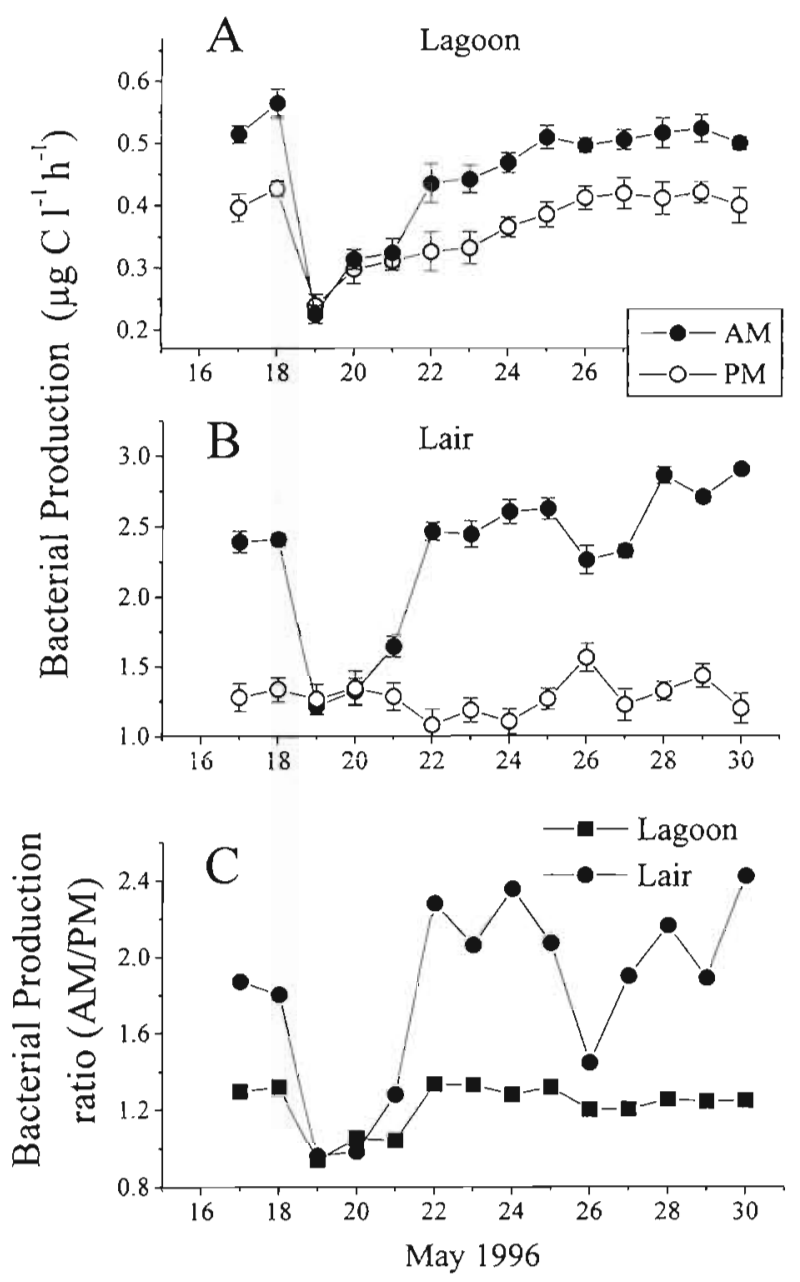

Fig. 2. Rates of bacterial secondary production (BP) in surface waters of (A) the oligotrophic lagoon and $(B)$ the eutrophic Lair; $(C)$ the ratio between bacterial production during early morning (AM) and late afternoon (PM) samples; vertical lines show \pm SD of triplicate measurements. Note that there were no significant differences in BP between morning and afternoon samples on May 19 to 20, when there was very heavy

rainfall (precipitation $\sim 275 \mathrm{~mm} \mathrm{~d}^{-1}$ ) and lots of clouds

$0.001)$ than those determined on samples taken in the morning (Fig. 2C). This was especially the case in samples taken from the eutrophic Lair, where mean rates of BP $\left(1.27 \pm 0.12 \mu \mathrm{g} \mathrm{C} \mathrm{l}^{-1} \mathrm{~h}^{-1}\right)$ in the afternoon were 1.81 times lower in comparison to morning samples $\left(2.30 \pm 0.53 \mu \mathrm{g} \mathrm{C} \mathrm{l}^{-1} \mathrm{~h}^{-1}\right)$. In the lagoon we found that afternoon rates of BP (mean $0.36 \pm 0.06 \mathrm{~g} \mathrm{C} \mathrm{l}^{-1} \mathrm{~h}^{-1}$ ) were on average 1.25 times lower (Fig. 2C) than in the morning (mean $0.45 \pm 0.10 \mathrm{~g} \mathrm{C} \mathrm{l}^{-1} \mathrm{~h}^{-1}$ ). BP rates determined in the lagoon varied between 0.22 and $0.56 \mathrm{~g} \mathrm{C} \mathrm{l}^{-1} \mathrm{~h}^{-1}$ and from 0.24 to $0.43 \mathrm{~g} \mathrm{C} \mathrm{l}^{-1} \mathrm{~h}^{-1}$ in the morning and afternoon, respectively (Fig. 2A). BP determined in The Lair fluctuated between 1.21 and $2.90 \mu \mathrm{g} \mathrm{Cl}^{-1} \mathrm{~h}^{-1}$ in the morning and between 1.08 and $1.56 \mu \mathrm{C} \mathrm{C}^{-1} \mathrm{~h}^{-1}$ in the afternoon (Fig. 2B). 
Table 1. Bacterial number (BN) and turnover time of biomass (TB) in the lagoon and Lair surface water samples in the morning and late afternoon $( \pm \mathrm{SD})$

\begin{tabular}{|c|c|c|c|c|c|c|c|c|}
\hline \multirow{3}{*}{$\begin{array}{l}\text { Date } \\
\text { (May 1996) }\end{array}$} & \multicolumn{4}{|c|}{ Lagoon } & \multicolumn{4}{|c|}{ Lair } \\
\hline & \multicolumn{2}{|c|}{ Morning } & \multicolumn{2}{|c|}{ Afternoon } & \multicolumn{2}{|c|}{ Morning } & \multicolumn{2}{|c|}{ Afternoon } \\
\hline & $\begin{array}{c}\mathrm{BN} \\
\left(\times 10^{8} 1^{-1}\right)\end{array}$ & $\begin{array}{l}\mathrm{TB} \\
(\mathrm{h})\end{array}$ & $\begin{array}{c}\text { BN } \\
\left(\times 10^{8} 1^{-1}\right)\end{array}$ & $\begin{array}{l}\text { TB } \\
\text { (h) }\end{array}$ & $\begin{array}{c}\mathrm{BN} \\
\left(\times 10^{8} \mathrm{l}^{-1}\right)\end{array}$ & $\begin{array}{l}\mathrm{TB} \\
\text { (h) }\end{array}$ & $\begin{array}{c}\mathrm{BN} \\
\left(\times 10^{8} 1^{-1}\right)\end{array}$ & $\begin{array}{l}\mathrm{TB} \\
\text { (h) }\end{array}$ \\
\hline 17 & $4.7 \pm 0.2$ & 17.3 & $4.1 \pm 0.2$ & 20.5 & $16.9 \pm 0.2$ & 16.5 & $13.9 \pm 0.3$ & 19.1 \\
\hline 20 & $3.1 \pm 0.2$ & 16.9 & $3.2 \pm 0.3$ & 16.6 & $11.4 \pm 0.3$ & 16.8 & $11.5 \pm 0.4$ & 16.5 \\
\hline 22 & $4.0 \pm 0.1$ & 17.5 & $3.3 \pm 0.1$ & 19.4 & $14.7 \pm 0.2$ & 15.2 & $12.7 \pm 0.7$ & 18.8 \\
\hline 25 & $4.4 \pm 0.1$ & 16.1 & $3.0 \pm 0.2$ & 20.9 & $16.6 \pm 0.3$ & 15.6 & $13.8 \pm 0.5$ & 21.2 \\
\hline 28 & $5.1 \pm 0.2$ & 18.3 & $4.2 \pm 0.2$ & 19.6 & $17.1 \pm 0.3$ & 15.5 & $14.5 \pm 0.5$ & 18.5 \\
\hline 29 & $5.4 \pm 0.2$ & 19.4 & $4.3 \pm 0.1$ & 20.5 & $17.7 \pm 0.2$ & 15.3 & $15.2 \pm 0.3$ & 19.2 \\
\hline 30 & $4.9 \pm 0.1$ & 18.3 & $3.9 \pm 0.3$ & 20.1 & $17.5 \pm 0.1$ & 14.1 & $15.1 \pm 0.7$ & 17.5 \\
\hline Mean & $4.5 \pm 0.8^{\mathrm{a}}$ & $17.7 \pm 1.1^{\mathrm{a}}$ & $3.7 \pm 0.5^{a}$ & $19.6 \pm 01.4^{\mathrm{a}}$ & $16.0 \pm 2.2^{\mathrm{a}}$ & $15.6 \pm 0.9^{b}$ & $13.8 \pm 1.3^{\mathrm{a}}$ & $18.7 \pm 1.5^{b}$ \\
\hline
\end{tabular}

Note that there were no significant differences in BP rates between morning and afternoon samples at both sampling sites during very heavy rainfall and cloudy days on May 19 to 20, 1996 (Fig. 2A,B).

\section{Bacterial abundance and turnover time of biomass}

There were significant differences in the specific growth rates of bacterial assemblages between water samples taken in the morning and afternoon at both sites. Bacteria grew faster, i.e. displayed shorter turnover times of their biomass, during early morning (Table 1). Lagoon bacterial biomass in the morning doubled on average every $17.7 \pm 1.1 \mathrm{~h}$, whereas during late afternoon their mean turnover times of biomass were noticeably longer $(19.6 \pm 1.4 \mathrm{~h})$. Turnover times of bacterial biomass estimated for morning and afternoon samples from The Lair varied between 14.1 and 16.8 (mean 15.6 \pm 0.9 ) and 16.5 and 21.2 (mean 18.7 \pm 1.5 ) h, respectively.

Average total number of bacteria in lagoon water determined in morning samples $\left(4.5 \pm 0.8 \times 10^{8}\right.$ cells $\left.1^{-1}\right)$ was $-21 \%$ higher than during late afternoon $(3.7 \pm$ $0.5 \times 10^{8}$ cells $1^{-1}$, Table 1 ). Bacterial abundance in The Lair also varied significantly between morning (aver-

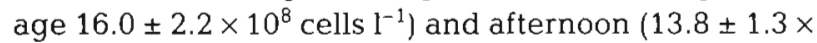
$10^{8}$ cells $\mathrm{l}^{-1}$ ) samples. During the day the average number of bacteria in The Lair decreased $15.9 \%$ in comparison to the abundance found in the afternoon.

We observed that bacteria in the oligotrophic lagoon samples were significantly smaller (ANOVA, $p=0.05$ ) than in the eutrophic Lair. Bacteria in the lagoon had an average cell volume of $0.066 \pm 0.011$ $\mu^{3}$ ( $\mathrm{n}=552,5$ samples), whereas cell volume of Lair bacteria was almost double $\left(0.107 \pm 0.032 \mu \mathrm{m}^{3}, \mathrm{n}=\right.$ 584,6 samples).

\section{Effect of solar radiation on $\left[{ }^{3} \mathrm{H}\right.$-methyl]thymidine and $\left[{ }^{3} \mathrm{H}\right]$ leucine incorporation}

Our field observations indicated that after the daylight period, rates of BP (Fig. 2) and number of bacteria (Table 1) markedly decreased. These variations in BP rates and number of bacteria may be due to changes in DNA and protein synthesis rates in bacteria that were exposed to harmful UV in solar radiation.

We determined rates of $\mathrm{TdR}$ and leucine incorporation into bacterial DNA and protein, respectively, in surface water samples that were exposed for $6 \mathrm{~h}$ to natural solar radiation. The results of these experiments are presented in Table 2 . There were enormous differences in DNA and protein synthesis by bacteria in sunlight-exposed samples in comparison to control samples incubated in the dark, not exposed to solar radiation, from both sampling sites. Exposure of bacteria to solar radiation resulted in a significant decrease in their rates of DNA and protein synthesis (ANOVA, $\mathrm{p}=0.001$ ).

TdR incorporation rates were on average 22 and $46 \%$ lower in comparison to dark controls in the lagoon and Lair, respectively. We found also severe inhibition of leucine incorporation into bacterial protein in samples that were exposed to solar radiation. Leucine incorporation rates in irradiated samples were on average 36 (lagoon) and 49\% (Lair) lower than in controls.

We did not find significant differences in TdR and $\left[{ }^{3} \mathrm{H}\right]$ leucine incorporation rates between dark control water samples in quartz and polystyrene incubation devices at both sampling sites (ANOVA, $p=0.001$; Table 2). Polystyrene flasks did not significantly change the spectrum of visible light and UV radiation (ANOVA, $\mathrm{p}=0.01$ ). They transmitted from 71 to $79 \%$ and 76 to $83 \%$ of UV ( 300 to $400 \mathrm{~nm}$ wavelength) and 
Table 2. Mean ( \pm SD of duplicates) rates of $\left[{ }^{3} \mathrm{H}\right.$-methyl]thymidine and $\left[{ }^{3} \mathrm{H}\right]$ leucine incorporation by bacteria in the lagoon and Lair water samples irradiated in quartz tubes and polystyrene flasks for $6 \mathrm{~h}$ with ambient solar radiation at the water surface. Control samples were not exposed to solar radiation. nd: not determined

\begin{tabular}{|c|c|c|c|c|c|c|c|c|}
\hline \multirow[t]{3}{*}{ Sampling site (19 } & \multicolumn{4}{|c|}{$\left[{ }^{3} \mathrm{H}\right.$-methyl $]$ thymidine $\left(\mathrm{nmol}^{-1} \mathrm{~h}^{-1}\right)$} & \multicolumn{4}{|c|}{$\left[{ }^{3} \mathrm{H}\right.$ ]leucine (nmol $\mathrm{l}^{-1} \mathrm{~h}^{-1}$ ) } \\
\hline & \multicolumn{2}{|c|}{ Quartz } & \multicolumn{2}{|c|}{ Polystyrene } & \multicolumn{2}{|c|}{ Quartz } & \multicolumn{2}{|c|}{ Polystyrene } \\
\hline & Control & Sunlight & Control & Sunlight & Control & Sunlight & Control & Sunlight \\
\hline Lagoon (May 17) & $0.112 \pm 0.011$ & $0.086 \pm 0.008$ & $0.117 \pm 0.013$ & $0.092 \pm 0.007$ & $4.216 \pm 0.025$ & $2.985 \pm 0.022$ & $4.228 \pm 0.024$ & $3.005 \pm 0.021$ \\
\hline Lagoon (May 19) & $0.105 \pm 0.008$ & $0.082 \pm 0.005$ & $0.111 \pm 0.004$ & $0.088 \pm 0.007$ & nd & nd & nd & nd \\
\hline Lagoon (May 20) & nd & nd & nd & nd & $3.995 \pm 0.025$ & $2.125 \pm 0.027$ & $3.935 \pm 0.033$ & $2.237 \pm 0.016$ \\
\hline Lagoon (May 21) & $0.110 \pm 0.005$ & $0.088 \pm 0.008$ & $0.108 \pm 0.004$ & $0.087 \pm 0.007$ & nd & nd & nd & nd \\
\hline Lair (May 18) & $0.445 \pm 0.012$ & $0.234 \pm 0.009$ & $0.452 \pm 0.008$ & $0.231 \pm 0.011$ & nd & nd & nd & nd \\
\hline Lair (May 19) & nd & nd & nd & nd & $5.937 \pm 0.045$ & $3.027 \pm 0.035$ & $6.006 \pm 0.023$ & $3.045 \pm 0.015$ \\
\hline Lair (May 23) & $0.428 \pm 0.012$ & $0.241 \pm 0.007$ & $0.415 \pm 0.009$ & $0.238 \pm 0.008$ & nd & nd & nd & nd \\
\hline Lair (May 24) & nd & nd & nd & nd & $5.238 \pm 0.022$ & $2.875 \pm 0.020$ & $5.325 \pm 0.015$ & $2.945 \pm 0.012$ \\
\hline Lair (May 25) & $0.440 \pm 0.010$ & $0.235 \pm 0.014$ & $0.437 \pm 0.009$ & $0.238 \pm 0.012$ & nd & nd & nd & nd \\
\hline Lair (May 27) & nd & nd & nd & nd & $5.775 \pm 0.014$ & $2.756 \pm 0.009$ & $5.812 \pm 0.011$ & $2.650 \pm 0.021$ \\
\hline
\end{tabular}

PAR, respectively (Fig. 3). Similar observations were reported by Herndil et al. (1993).

\section{Bacterial production and growth in water samples previously exposed to natural solar radiation}

Filter-sterilized water samples were exposed to natural solar radiation between $10: 00$ and $13: 00 \mathrm{~h}$ and 10:00 and 16:00 h (local time). Table 3 presents total solar radiation ( 300 to $700 \mathrm{~nm}$ ) and UV radiation (300 to $400 \mathrm{~nm}$ ) in polystyrene vessels during the experiment. UV radiation constituted 10.9 to $13.7 \%$ (mean 12.5 $\pm 1.2 \%$ ) and 10.9 to $14.5 \%$ (mean $12.8 \pm 1.2 \%$ ) of the total solar radiation between $10: 00$ and $13: 00 \mathrm{~h}$ and 10:00 and $16: 00 \mathrm{~h}$, respectively.

We observed a significant increase in rates of bacterial production in water samples in situ exposed to ambient sunlight (Fig. 4). After $24 \mathrm{~h}$ growth, the bacteria in the lagoon samples exposed to sunlight increased their production rates -3 times in comparison to dark control samples. More dramatic changes in BP were observed in the eutrophic water samples from The Lair previously exposed to sunlight (Fig. 4). BP in The Lair samples was 2.4 and 4.4 times higher than in dark controls when exposed to solar radiation over 3 and $6 \mathrm{~h}$, respectively.

Table 3. Range values of total solar and UV (300 to $400 \mathrm{~nm}$ ) radiation $\left(\mathrm{W} \mathrm{m} \mathrm{m}^{-2}\right.$ ) reaching water samples in polystyrene flasks incubated in the lagoon at $0.25 \mathrm{~m}$ depth (May 28, 1996). In parentheses: mean \pm SD values

\begin{tabular}{|lcc|}
\hline & \multicolumn{3}{c|}{ Local time } \\
& $10: 00$ to $13: 00 \mathrm{~h}$ & $10: 00$ to $16: 00 \mathrm{~h}$ \\
\hline $\begin{array}{l}\text { Total solar radiation } \\
\text { UV radiation }\end{array}$ & $178-275(241 \pm 35)$ & $178-324(257 \pm 41)$ \\
& $20-36(30 \pm 5)$ & $20-45(33 \pm 6)$ \\
\hline
\end{tabular}

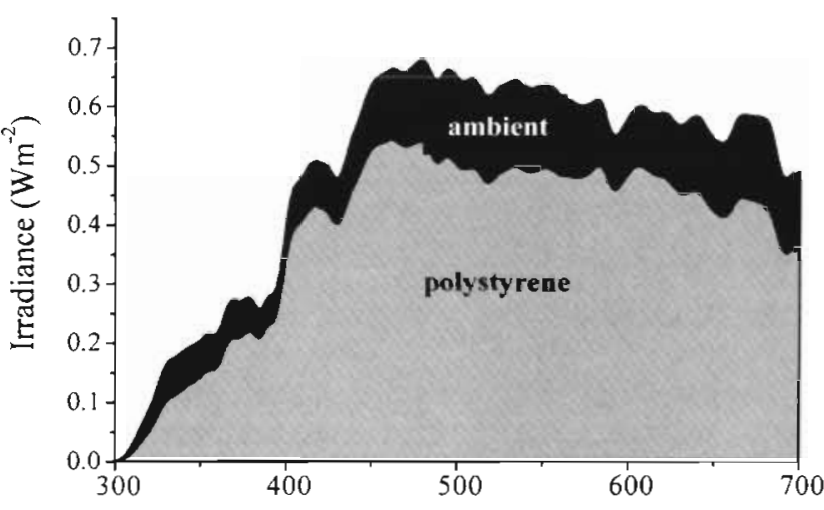

Fig. 3. Comparison of irradiance of ambient sunlight and irradiance passing through polystyrene flasks

There were also pronounced changes in the growth rates of bacteria inoculated into samples previously radiated with sunlight (Table 4). Exposure of water samples from the lagoon and Lair to ambient solar radiation at the water surface resulted in acceleration of bacterial divisions; bacterial growth rates were on average 2 times higher in comparison to the untreated control samples. Doubling time of bacteria significantly shortened from 18.8 (lagoon) and 14.5 (Lair) $\mathrm{h}$ in control samples to 8.5 and $7.1 \mathrm{~h}$, respectively, in samples that were previously exposed to solar radiation (Table 4).

Epifluorescence microscopy revealed that bacteria of sunlight-irradiated water samples from the lagoon and The Lair increased their cell volumes during the $24 \mathrm{~h}$ re-growth experiment (ANOVA, $\mathrm{p}=0.01)$. The bacterial community was mainly composed of large rods ( 76 to $84 \%$ ). The average cell volume of the native lagoon bacteria increased from $0.058 \pm 0.011(n=320)$ to $0.075 \pm$ $0.008 \mu \mathrm{m}^{3}$ ( $\mathrm{n}=300$ ), i.e. $\sim 1.3$ times. Bacteria grown in The Lair water exposed to solar radiation for $6 \mathrm{~h}$ enlarged their cell size even more dramatically: 
their average cell volume increased -1.9 times from $0.105 \pm 0.023(\mathrm{n}=340)$ to $0.195 \pm 0.024 \mu \mathrm{m}^{3}(\mathrm{n}=32.5)$ after $24 \mathrm{~h}$.

\section{DISCUSSION}

This study shows that bacterial production and growth in subtropical coastal surface waters may be both directly inhibited and indirectly stimulated by solar radiation. Direct inhibition of the studied processes was observed during the daytime, while indirect stimulation occurred during nighttime, when bacteria were able to recover from solar radiation stress. This paradox in impact of solar radiation on bacterial metabolism is due to the effects of UV radiation on cellular components and dissolved organic matter in water samples. The major inhibitory effects of UV radiation at the cellular level results in damage to DNA, proteins and enzymes (Swenson \& Setlow 1966, Regan et al. 1992, Müller-Niklas et al. 1995, Buma et al. 1996, Ekelund 1996, Lindell \& Edling 1996). UV radiation directly damages DNA by inducing bulky adducts (e.g. thymine dimers) that block replication and transcription (Mitchell \& Karentz 1993). At the environmental level, UV radiation transforms and photo-oxidizes a variety of DOC constituents (Mopper et al. 1991). These products of UV photodegradation of DOC may have inhibitory and/or stimulatory consequences to microbial metabolism in aquatic ecosystems (Herndl et al. 1993, Lindell et al. 1996, Aas et al. 1996, Bergeron \& Vincent 1997).

Several recent studies considered the significant role of high solar and UV-B radiation in photooxidation of natural dissolved organic compounds in freshwater and marine systems (Kieber et al. 1989, Dahlén et al. 1996). The interactions between DOC and solar radiation are very complex. Organic molecules of the DOC pool are predominant factors attenuating the penetration of solar radiation of both visible and UV wavelengths in natural waters (Williamson et al. 1996, Morris \& Hargreaves 1997). This is extremely important because it protects organisms from harmful UV-B radiation and limits the depth to which phytoplankton photosynthesis can occur. DOC photo-oxidized by UV radiation releases a number of chemically and biologically reactive by-products, including hydrogen peroxide, hydroxide radials, carbonyl compounds, $\alpha$-keto acids, ammonia and organic nitrogen compounds. Bioassay studies have documented that the photolytic by-products of UV-B-DOC interactions are more available for bacterial metabolism (than the original molecules) and stimulate bacterial growth and production (Lindell et al. 1995, Wetzel et al. 1995).

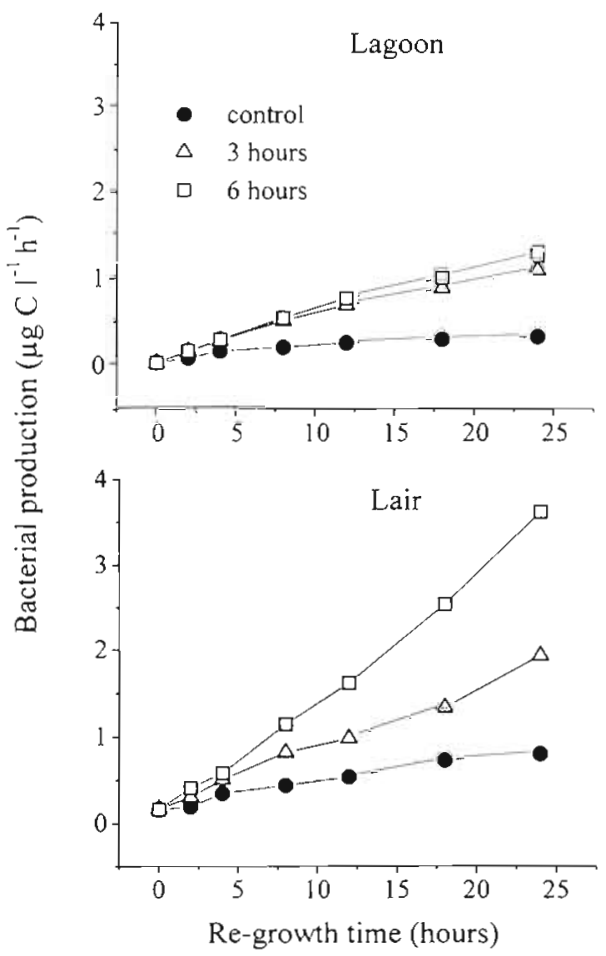

Fig. 4. Production of bacteria during the bioassay experiment in the lagoon and The Lair water samples previously exposed to natural solar radiation

We observed a significant decrease in in situ rates of bacterial production and growth in water samples taken in the late afternoon in comparison to samples collected in the early morning (Fig. 2, Table 1). Bacterial production and their division rates from both sampling sites responded similarly to solar irradiance. The negative changes in bacterial production and growth rates, however, were more drastically pronounced in The Lair. One possible explanation of the observed negative changes in bacterial metabolism may be severe photoinhibition of DNA and protein synthesis in microbial cells at the water surface (Table 2; Regan et

Table 4. Growth rates and doubling times of bacteria re-grown in the lagoon and Lair water samples irradiated for 3 and $6 \mathrm{~h}$ with ambient solar radiation at the water surface $( \pm S D)$. Growth rates are arithmetic means of values resulted from 2 independent methods used for calculation, i.e. slopes of linear regressions of natural logarithms of thymidine incorporation rates and bacterial numbers, determined simultaneously

\begin{tabular}{|c|c|c|c|c|}
\hline \multirow[t]{2}{*}{ Treatment } & \multicolumn{2}{|c|}{ Lagoon } & \multicolumn{2}{|c|}{ Lair } \\
\hline & $\begin{array}{l}\text { Growth } \\
\text { rate }\left(\mathrm{h}^{-1}\right)\end{array}$ & $\begin{array}{l}\text { Doubling } \\
\text { time }(\mathrm{h})\end{array}$ & $\begin{array}{l}\text { Growth } \\
\text { rate }\left(\mathrm{h}^{-1}\right)\end{array}$ & $\begin{array}{l}\text { Doubling } \\
\text { time (h) }\end{array}$ \\
\hline Dark (control) & $0.037 \pm 0.007$ & 18.8 & $0.048 \pm 0.009$ & 14.5 \\
\hline Solar radiation & & & & \\
\hline $3 \mathrm{~h}$ & $0.079 \pm 0.016$ & 8.7 & $0.071 \pm 0.011$ & 9.7 \\
\hline $6 \mathrm{~h}$ & $0.081 \pm 0.021$ & 8.5 & $0.096 \pm 0.013$ & 7.1 \\
\hline
\end{tabular}


al. 1992, Herndl et al. 1993, Buma et al. 1996, Jeffrey et al. 1996) and/or photoproduction of inhibitory substances after photo-oxidation of DOC constituents during the daytime (Mopper et al. 1991).

After sunset, bacteria recovered from UV stress, enhanced their metabolism, and markedly increased their growth rates and biomass production. We found in samples taken from the lagoon and Lair in the early morning that bacterial production was on average 1.21 \pm 0.13 and $1.88 \pm 0.52$ times higher than in the afternoon samples, respectively (Fig. 2C). Similar observations were reported by Jeffrey et al. (1996) and Pakulski et al. (1998) in the Gulf of Mexico. They found that bacteria exhibited nighttime repair of DNA damage after diurnal exposure to solar radiation. There are many DNA repair mechanisms in bacterial cells. Repair of bacterial DNA in aquatic ecosystems may be either light dependent via the action of photolyase (Mitcheli \& Karentz 1993) and/or light independent via the SOS response mechanism that includes action of proteins such as recA (Miller \& Kokjohn 1990).

We suggest that exposure of natural waters to solar radiation resulted not only in inhibition of bacterial DNA and protein synthesis, but also in their enrichment in labile by-products of DOC photo-oxidation that consequently enhanced overall bacterial metabolism during nighttime, after their recovery from UV stress. Several studies reported that bacteria may be stimulated by the photochemical transformation of high-molecular-weight DOC (non-readily utilizable) into low-molecular-weight subunits that are easily utilizable by these microorganisms (Lindell et al. 1995, 1996, Wetzel et al. 1995, Bano et al. 1998). Results of our bioassay experiments are consistent with the above suggestion (Table 4, Fig 4). We found a large increase in cell volume, and also in growth rates and production of bacteria in samples previously irradiated with sunlight. Similar changes in biomass production and cell volume of lake bacteria due to exposure of DOC to light irradiance were reported by Lindell et al. (1995). It was documented that cell volume of bacteria is positively proportional to their metabolic activities and nutrient content and availability (Lee \& Fuhrman 1987, Gasol et al. 1995), and negatively proportional to the grazing pressure of bacterivores in aquatic environments (del Giorgio et al. 1996). During our bioassay experiments bacteria grew in water samples in. absence of grazers, which were excluded by filtration from the inoculum. Thus, the observed increase in bacterial cell size could be due to both processes: photooxidation of non-readily utilizable DOC, and subsequent release of usable substrates, and absence of grazing.

This study revealed that solar radiation can directly and adversely alter bacterial production and growth over diel cycles in coastal subtropical waters. These physico-chemical and biological interactions in coastal waters between sunlight $\rightarrow \mathrm{DOC} \rightarrow$ heterotrophic bacteria may have important implications at both the ecosystem and global levels. At the ecosystem level, increased bacterial production and growth rates will transfer a larger proportion of energy and carbon flow into the microbial compartment of the aquatic food web. This may increase mineralization of organic matter and regeneration of inorganic nutrients, and respiration rates of bacteria and bacterivores, resulting in significant enrichment of natural waters with carbon dioxide. Moreover, photooxidation of DOC itself results in $\mathrm{CO}_{2}$ production and oxygen consumption in natural waters. Decreased concentrations of DOC in water may simultaneously increase the penetration of biologically harmful UV wavelengths to deeper parts of aquatic ecosystems (Morris \& Hargreaves 1997), thus affecting phytoplankton photosynthesis (Helbling et al. 1992) and decreasing their organic matter and oxygen production. Finally, these biologically unbalanced concentrations of carbon dioxide and oxygen in aquatic ecosystems may significantly influence their water-air exchange rates. Clearly, in light of the awareness of global ozone depletion and harmful effects of UV radiation, the interactions of solar radiation in aquatic ecosystems urgently deserve further study.

Acknowledgements. This study was supported by funds from the Research Exchange Fund (No. 1231P017), Office of the Provost, and Short-Term Visitors Program of the Office of Fellowships and Grants, Smithsonian Institution, awarded to R.J.C. We thank Dr Klaus Ruetzler (National Museum of Natural History, Smithsonian Institution) for the use of the facilities at Carrie Bow Cay, Belize, and Dr M. P. Lesser (Department of Zoology, University of New Hampshire) for measurements of solar radiation during our experiments. This paper is contribution No. 569 from the Caribbean Coral Reef Ecosystem Program of the Smithsonian Institution. We are very grateful to 2 conscientious reviewers, whose comments helped to improve this paper considerably.

\section{LITERATURE CITED}

Aas P, Lyons MM, Pledger R, Mitchell DL, Jeffrey WH (1996) Inhibition of bacterial activities by solar radiation in nearshore waters and the Gulf of Mexico. Aquat Microb Ecol 11:229-238

Alongi DM (1994) The role of bacteria in nutrient cycling in tropical mangrove and other coastal benthic ecosystems. Hyctrobiologia 285:19-32

Azam F, Ammerman JW (1984) Mechanisms of organic matter utilization by marine bacterioplankton. In: Holm-Hansen $O$, Bolis L, Gilles R (eds) Lecture notes on coastal and estuarine studies. Springer-Verlag, New York, p 45-54

Azam F, Fenchel $T$, Field JG, Gray JS, Meyer-Reil LA, Thingstad F (1983) The ecological role of water-column microbes in the sea. Mar Ecol Prog Ser 10:257-263

Bailey CA, Niehof RA, Tabor PS (1983) Inhibitory effect of 
solar radiation on amino acid uptake in Chesapeake Bay bacteria. Appl Environ Microbiol 46:44-49

Bano N, Moran MA, Hodson RE (1998) Photochemical formation of labile organic matter from two components of dissolved organic carbon in a freshwater wetland. Aquat Microb Ecol 16:95-102

Bergeron M, Vincent WF (1997) Microbial food web responses to phosphorus supply and solar UV radiation in a subarctic lake. Aquat Microb Ecol 12:239-249

Buma AGJ, Van Hannen EJ, Veldhuis MJW, Gieskes WWC (1996) UV-B induces DNA damage and DNA synthesis delay in the marine diatom Cyclotella sp. Sci Mar 60: $101-106$

Cho BC, Azam F (1990) Biogeochemical significance of bacterial biomass in the ocean's euphotic zone. Mar Ecol Prog Ser 63:253-259

Chróst RJ (1991) Microbial enzymes in aquatic environments. Springer-Verlag, New York

Chróst RJ (1993) Enzymatic transformation of organic matter in aquatic environments. In: Guerrero R, Pedrós-Alió C (eds) Trends in microbial ecology. Spanish Society for Microbiology, Barcelona, p 401-406

Chróst RJ (1994) Microbial enzymatic degradation and utilization of organic matter. In: Overbeck J, Chróst RJ (eds) Microbial ecology of Lake Plußsee. Springer-Verlag, New York, p 118-174

Chróst RJ, Rai H (1994) Bacterial production. In: Overbeck J, Chróst RJ (eds) Microbial ecology of lake Plußsee. Springer-Verlag, New York, p 45-65

Chróst RJ, Overbeck J, Wcisło R (1988) Evaluation of the $\left[{ }^{3} \mathrm{H}\right]$ thymidine method for estimating bacterial growth rates and production in lake water: re-examination and methological comments. Acta Microbiol Polon 37:95-112

Cullen JC, Neale PJ (1994) Ultraviolet radiation, ozone depletion, and marine photosynthesis. Photosynth Res 39 : $303-320$

Dahlén J, Bertillson S, Pettersson C (1996) Effects of UV-A irradiation on dissolved organic matter in humic surface waters. Environ Internat 22:501-506

del Giorgio PA, Gasol JM, Vagué D, Mura P, Agustí S, Duarte CM (1996) Bacterioplankton community structure: protists control net production and the proportion of active bacteria in a coastal marine community. Limnol Oceanogr 41: $1169-1179$

Ducklow HW, Carlson CA (1992) Oceanic bacterial production. In: Marshall KC (ed) Advances in microbial ecology. Plenum Press, New York, p 113-181

Ekelund NGA (1996) Effects of protein synthesis inhibitors on photoinhibition nu UV-B $(280-320 \mathrm{~nm})$ radiation in the flagellate Euglena gracilis. Sci Mar 60:95-100

Faust MA, Gulledge RA (1996) Associations of microalgae and meiofauna in floating detritus at a mangrove island, Twin Cays, Belize. J Exp Mar Biol Ecol 197:159-175

Fleischman EM (1989) The measurement and penetration of ultraviolet radiation into tropical marine water. Limnol Oceanogr 34:1623-1629

Gasol JP, del Giorgio PA, Massana R, Duarte CM (1995) Active versus inactive bacteria: size-dependence in a coastal marine plankton community. Mar Ecol Prog Ser 128:91-97

Häder DP (1996) Effects of enhanced solar UV-B radiation on phytoplankton. Sci Mar 60:59-63

Helbling EW, Villafane V, Ferrario M, Holm-Hansen O (1992) Impact of natural ultraviolet radiation on rates of photosynthesis and on specific marine phytoplankton species. Mar Ecol Prog Ser 80:89-100

Helsel DR, Hirsch RM (1992) Statistical methods in water resources. Elsevier, Amsterdam

Herndl GJ, Müller-Niklas G, Frick J (1993) Major role of ultraviolet-B in controlling bacterioplankton growth in the surface layer of the ocean. Nature 361:717-719

Holm-Hansen O, Helbling EW, Lubin D (1993a) Ultraviolet radiation in Antarctica: inhibition of primary production. Photochem Photobiol 58:567-570

Holm-Hansen O, Lubin D, Helbling EW (1993b) Ultravioìet radiation and its effects on organisms in aquatic environments. In: Young AR, Björn L, Moan J, Nultsch W (eds) Environmental UV photobiology. Plenum Press, London, $\mathrm{p}$ 379-425

Jeffrey WH, Pledger RJ, Aas P, Hager S, Coffin RB, von Haven R, Mitchell DL (1996) Diel and depth profiles of DNA photodamage in bacterioplankton exposed to ambient solar ultraviolet radiation. Mar Ecol Prog Ser 137: 283-291

Jerlov NG (1950) Ultra-violet radiation in the sea. Nature 116: $111-112$

Karentz D, Lutze LH (1990) Evaluation of biologically harmful ultraviolet radiation in Antarctica with a biological dosimeter designed for aquatic environments. Limnol Oceanogr 35:549-561

Kieber DJ, McDaniel J, Mopper K (1989) Photochemical source of biological substrates in sea water: implications for carbon cycling. Nature 341:637-639

Kirk JTO (1994) Optics of UV-B radiation in natural waters Arch Hydrobiol Beih Ergebn Limnol 43:1-16

Lampert W (1989) The adaptative significance of diel vertical migration of zooplankton. Funct Ecol 3:21-27

Larchar W (1995) Physiological plant ecology. Springer, New York

Lee S, Fuhrman JA (1987) Relationships between biovolume and biomass of naturally derived marine bacterioplankton. Appl Environ Microbiol 53:1298-1303

Lesser MP (1996) Elevated temperatures and ultraviolet radiation cause oxidative stress and inhibit photosynthesis in symbiotic dinoflagellates. Limnol Oceanogr 41:271-283

Lindell M, Edling $H$ (1996) Influence of light on bacterioplankton in a tropical lake. Hydrobiologia 323:67-73

Lindell M, Granéli W, Tranvik LJ (1995) Enhanced bacterial growth in response to photochemical transformation of dissolved organic matter. Limnol Oceanogr 40:195-199

Lindell M, Granéli W, Tranvik LJ (1996) Effects of sunlight on bacterial growth in lakes of different humic content. Aquat Microb Ecol 11:135-141

Luecke C, O'Brien WJ (1981) Phototoxicity and fish predation: Selective factors in colour morphs in Heterocope. Limnol Oceanogr 26:454-460

Madronich S (1992) Implications of recent total atmospheric ozone measurements for biologically active ultraviolet radiation reaching the earth's surface. Geophys Res Lett 19:37-40

Madronich S (1994) Increases in biologically damaging UV-B radiation due to stratospheric ozone reductions. A brief review. Arch Hydrobiol Beih Ergebn Limnol 43:17-30

Miller RV, Kokjohn TA (1990) General microbiology of recA: environmental and evolutionary significance. Annu Rev Microbiol 44:365-394

Mitchell DL, Karentz D (1993) The induction and repair of DNA photodamage in the environment. In: Young $A R$, Björn L, Moan J, Nultsch W (eds) Environmental UV photobiology. Plenum Press, London, p 345-377

Mopper K, Zhou X, Kieber RJ, Kieber DJ, Sikorski RJ, Jones RD (1991) Photochemical degradation of dissolved organic carbon and its impact on the oceanic carbon cycle. Nature $353: 60-62$ 
Morris DP, Hargreaves BR (1997) The role of photochemical degradation of dissolved organic carbon in regulating UV transparency of three lakes on the Pocono Plateau. Limnol Oceanogr 42:239-249

Müller-Niklas G, Heissenberger A, Puškarić S. Herndl G.J (1995) Ultraviolet-B radiation and bacterial metabolism in coastal waters. Aquat Microb Ecol 9:111-116

Münster U, Chróst RJ (1990) Origin, composition, and microbial utilization of dissolved organic matter. In: Overbeck J, Chróst RJ (eds) Aquatic microbial ecology: biochemical and molecular approaches. Springer-Verlag, New York, p $8-46$

Nielsen T, Ekelund NGA (1995) Influence of solar ultraviolet radiation on photosynthesis and motility of marine phytoplankton. FEMS Microbiol Ecol 18:281-288

Pakulski JD, Aas P, Jeffrey W, Lyons M, Van Waasbergen L, Mitchell D, Coffin R (1998) Influence of light on bacterioplankton production and respiration in a subtropical coral reef. Aquat Microb Ecol 14:137-148

Porter KG, Feig YS (1980) The use of DAPI for identifying and counting aquatic microflora. Limnol Oceanogr 25:943-948

Regan JD, Carrier WL, Gucinski H, Olla BL, Yoshida H, Fujimuira RK, Wicklung RI (1992) DNA as solal dosinteite in the ocean. Phototochem Photobiol 56:35-42

Riemann B, Sondergaard M (1984) Measurements of diel rates of bacterial secondary production in aquatic environments. Appl Environ Microbiol 47:632-638

Ruetzler K, Feller C (1988) Mangrove swamp communities. Oceanus 30:16-24

Sanders RW, Caron DA, Berninger UG (1992) Relationships between bacteria and heterotrophic nanoplankton in marine and fresh waters: an inter-ecosystem comparison. Mar Ecol Prog Ser 86:1-14

Scully NM, Lean DRS (1994) The attenuation of ultraviolet radiation in temperate lakes. Arch Hydrobiol Beih Ergebn Limnol 43:135-144

Siebeck O, Böhm U (1994) Challenges for an appraisal of UV$B$ effects upon planktonic crustaceans under natural radiation conditions with a non-migrating (Daphnia pulex) and a migrating cladoceran (Daphnia galeata). Arch Hydrobiol Beih Ergebn Limnol 43:197-206

Sieracki ME, Sieburth JMcN (1986) Sunlight-induced growth and delay of planktonic marine bacteria in filtered seawater. Mar Ecol Prog Ser 33:19-27

Simon M, Azam F (1989) Protein content and protein synthe-

Editorial responsibility: David Karl,

Honolulu, Hawaii, USA sis rates of planktonic marine bacteria. Mar Ecol Prog Ser 51:201-213

Smith RC, Baker KS (1979) Penetration of UV-B and biologically effective dose-rates in natural waters. Photochem Photobiol 29:311-323

Smith RC, Baker KS (1981) Optical properties of the clearest natural waters $(200-800 \mathrm{~nm})$. Appl Opt 20:177-184

Sommaruga R, Oberleiter A, Psenner R (1996) Effect of UV radiation on the bacterivory of a heterotrophic nanoflagellate. Appl Environ Microbiol 62:4395-4400

Sundbäck K, Nilsson C, Odmark S, Wulff A (1996) Does ambient UV-B radiation influence marine diatom-dominated microbial mats? A case study. Aquat Microb Ecol 11: $151-159$

Suttle CA, Chan AM, Chen F, Garza DR (1993) Cyanophages and sunlight: a paradox. In: Guerrero R, Pedrós-Alió C (eds) Trends in microbial ecology. Spanish Society for Microbiology, Barcelona, p 303-308

Swenson PA, Setlow RB (1966) Effects of ultraviolet radiation on macromolecular synthesis in Escherichia coli. J Mol Biol 15:201-219

Tevini M (1993) UV-B radiation and ozone depletion. Lewis Lewis

Weinbauer MG, Wilhelm SW, Suttle CA, Garza DR (1997) Photoreactivation compensates for UV damage and restores infectivity to natural marine virus communities Appl Environ Microbiol 63:2200-2205

Wetzel RG, Hatcher PG, Bianchi TS (1995) Natural photolysis by ultraviolet irradiance of recalcitrant dissolved organic matter to simple substrates for rapid bacterial metabolism. Limnol Oceanogr 40:1369-1380

Wilhelm SW, Weinbauer MG, Suttle CA, Pledger RJ, Mitchell DL (1998) Measurements of DNA damage and photoreactivation imply that most viruses in marine surface waters are infective. Aquat Microb Ecol 14:215-222

Williams PJLeB (1981) Incorporation of microheterotrophic processes into the classical paradigm of the planktonic food web. Kiel Meeresforsch 5:1-28

Williamson CE (1995) What role does UV-B radiation play in freshwater ecosystems? Limnol Oceanogr 40:386-392

Williamson CE, Sternberger RS, Morris DP, Frost TM, Paulsen SG (1996) Ultraviolet radiation in North American lakes attenuation estimates from DOC measurements and implications for plankton communities. Limnol Oceanogr 41 . $1024-1034$

Submitted: November 6, 1998; Accepted: June 2, 1999

Proofs received from author(s): October 29, 1999 